\section{Urologia \\ Internationalis}

\section{A. Erdem Canda ${ }^{a}$ \\ Mehtap G. Cinar ${ }^{b}$ \\ Burak Turnac \\ M. Oguz Sahina}

${ }^{a}$ Manisa State Hospital, Urology Clinic, Manisa; ${ }^{\circ}$ Department of Pharmacology and Clinical Pharmacology, and 'Department of Urology, Ege University School of Medicine, Izmir, Turkey
Urol Int 2008;80:341-354

DOI: $10.1159 / 000132690$

\title{
Pharmacologic Targets on the Female Urethra
}

\section{Key Words}

Female urethra - Pharmacology • Transmitters • Receptors •

Stress urinary incontinence $\cdot$ Management

\section{Abstract}

Introduction: This article reviews the mechanisms affecting contraction and relaxation of the urethra in order to establish a basis for current and future treatments for urinary incontinence in women. Material and Methods: A review of the English literature using MEDLINE was performed between 1970 and 2008 on female urethra pharmacology, urinary incontinence, and mechanisms involved in contraction and relaxation of the female human urethra. Results: $\alpha$-Adrenoceptors (ARs) cause contraction and $\beta$-ARs cause relaxation. Use of selective $\alpha$-agonist and $\beta$-AR blocker agents might have potential for the treatment of stress urinary incontinence. Tolerable doses of cholinergic agonists did not have significant effects on intraurethral pressure. $\mathrm{Ni}$ tric oxide seems to be the major nonadrenergic-noncholinergic inhibitory transmitter causing relaxation. c-kit-positive interstitial cells seem to regulate urethral tone. The roles of adenosine triphosphate and carbon monoxide have not been fully investigated in humans. Neuropeptides function similarly to the urinary bladder. Prostanoids cause urethral contraction and relaxation depending on their subtypes. Serotonin enhances the strength of urethral sphincteric contractions. The Rho-kinase pathway also appears to be modulating smooth muscle contraction in the urethra. Conclu- sions: Understanding of the urethral function and pharmacology may lead to the development of promising new agents which might be useful in the management of urinary incontinence in women.

Copyright $\odot 2008$ S. Karger AG, Basel

Urinary incontinence is a common medical condition affecting many women worldwide. Approximately onethird of elderly individuals suffer from urinary incontinence [1] and almost $40 \%$ of younger women aged 20-45 years suffer from urinary incontinence symptoms that significantly affect their quality of life [2]. The prevalence of stress, urge, and mixed urinary incontinence has been reported to be 40, 25, and 29\%, respectively, in Turkey [3]. Stress urinary incontinence (SUI) is defined as involuntary leakage of urine by effort, exertion, sneezing or coughing. As such, pelvic floor muscle training, behavioral therapies and surgery are the main treatment options.

The lower urinary tract (LUT) consists of the urinary bladder and urethra. Two principal functions of the urinary bladder are urine storage and emptying. The urethra maintains urinary continence by relaxing during the voiding phase and contracting during the urine storage phase [4].

Several transmitters and receptors are reported to be involved in LUT physiology. In order to fully understand the clinical implications of LUT function, it is important

\section{KARGER \\ Fax +4161306 1234 E-Mail karger@karger.ch} www.karger.com

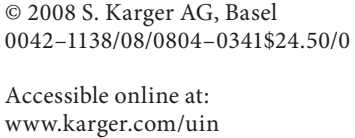

Dr. A. Erdem Canda

Manisa State Hospital, Urology Clinic

TR-Manisa 45350 (Turkey)

Tel. +90 532261 1105, Fax +90232 2345534

E-Mail aecanda@yahoo.com 
to transform the scientific basis of LUT physiological and pharmacological mechanisms to clinical practice. In our previous review, we summarized the physiology and pharmacology of the human urinary bladder [5]. In order to complement our previous work, the aim of the present review is to outline the pathways involved in the contraction and relaxation of the human female urethra and discuss their significance related to current and future pharmacological therapy for urinary incontinence in women.

\section{Pelvic Floor Problems/Dysfunction and SUI}

Although intrinsic urethral dysfunction is an etiological factor for the onset of urinary incontinence in women, pelvic floor problems and dysfunction are more important for the development of female urinary incontinence.

The levator ani muscles, endopelvic fascia, muscular structures of the sphincter and the pelvic floor musculature comprise a single system maintaining urinary continence in women. The physiological organization of Onuf's nuclei and of levator ani motorneurons together with reflex control of the tonic activity is important for the formation of maintained force in slow-twitch muscle fibers which is an essential part of the normal urinary continence function [6].

Pregnancy and vaginal delivery are the main etiological factors responsible for the formation of genuine SUI and pelvic floor damage leading to pelvic floor dysfunction and problems in women. Most of the pelvic floor damage occurs during the first delivery. Therefore, childbirth is one of the most important causes of SUI in women, particularly following long second stages of labor, traumatic deliveries, large babies and in multigravidae [7]. Pudendal nerve damage mostly occurs after forceps delivery, increased duration of second stage of labor, third-degree perineal tear and high birth weight [8]. Reduced collagen content of the pelvic floor tissue causing pelvic floor dysfunction in patients with pelvic organ prolapse and/or SUI has been demonstrated before [9]. Similarly, defects in the support of the anterior pelvic compartment result in a number of anatomic and physiologic problems such as SUI in women [10]. Although less frequently seen in women, pelvic fracture is a risk factor for pelvic floor dysfunction [11].

Noninvasive treatment options for female SUI include pelvic floor muscle training, lifestyle interventions, bladder retraining and pharmacotherapy, whereas more inva- sive options include anti-incontinence devices, periurethral bulking agent injectables and surgery [12]. Postpartum pelvic floor exercises seem to be an effective conservative treatment modality in decreasing postpartum urinary incontinence, suggesting the importance of pelvic floor problems in the formation of SUI in women [13].

\section{Structure and Innervation of the Female Urethra}

The female urethra is surrounded by 3 layers of muscle tissue: (1) thick inner (central) longitudinal smooth muscle layer, (2) thin, middle, circular smooth muscle layer, and (3) outer striated muscle layer (rhabdosphincter) (fig. 1). The rhabdosphincter surrounds the longitudinal mid-point of the urethra and is thickest anteriorly and thinnest posteriorly. Circular and longitudinal smooth muscles and rhabdosphincter are tonically active during the storage of urine. The rhabdosphincter becomes active when abdominal pressure rises. However, during voiding all urethral muscles relax. In the elderly and particularly after menopause, rhabdosphincter atrophies at the level of the bladder neck and dorsal urethral wall are strongly associated with developing SUI [14].

The female urethra is innervated by the parasympathetic, sympathetic and somatic nervous system, and all include sensory afferent fibers (fig. 1) [15, 16].

\section{Pelvic Nerve}

Preganglionic parasympathetic neurons are located in the sacral spinal cord and their axons make synapsis with postganglionic neurons located in the pelvic plexus. These pathways are mainly cholinergic but they also include purinergic, peptidergic and nitrergic pathways innervating the urethral smooth muscles $[17,18]$. Sensory fibers originate from the dorsal root ganglia (DRG) of the sacral spinal cord and are composed of myelinated (A $\delta$ ) and unmyelinated (C) fibers. Urinary tract infection, bladder outlet obstruction and spinal cord injuries may affect these fibers, leading to overactive bladder and urinary incontinence.

\section{Hypogastric Nerve}

Efferent fibers from the inferior mesenteric ganglion and fibers in the upper lumbar spinal cord form the hypogastric nerve. The main transmitter involved in the sympathetic postganglionic fibers is noradrenaline (NA), but purinergic and peptidergic transmitters also take part in the neurotransmission process. Hypogastric nerve 
Fig. 1. Structure and innervation of the female urethra.

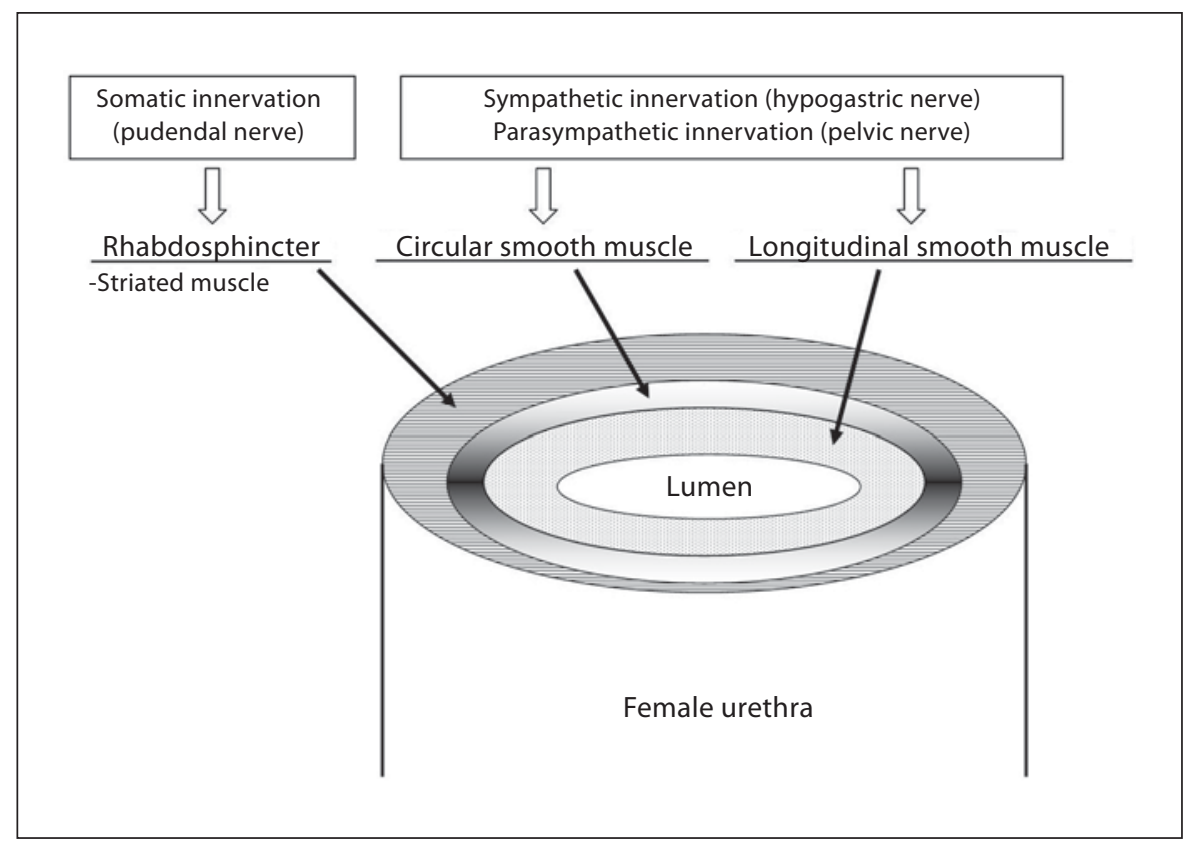

innervates the longitudinal and circular smooth muscle layers in the bladder neck and urethra. Sensory fibers originate from the upper lumbar DRG and innervate the pelvic viscera [19].

\section{Pudendal Nerve}

The pudendal nerve mainly contains motor fibers originating from Onufrowicz's nucleus (Onuf's nucleus) located in the ventral horn of the sacral spinal cord innervating the urethral rhabdosphincter, external anal sphincter, compressor urethrae and urethrovaginal sphincter muscles. The pudendal nerve has also sensory fibers originating from the sacral DRG innervating the urethra, rectum, clitoris and perineal skin [20]. However, sympathetic fibers compose a minor component innervating the vasculature of the pelvic organs.

\section{Pathways Involved in Contraction and Relaxation of the Female Urethra}

Complex interactions between bladder neck and urethra maintain urinary continence in women. However, these mechanisms are not fully elucidated. Mucosal seal effect of the urethra, a competent bladder neck and a functional urethral sphincter are the principal mechanisms maintaining urethral closure and continence in women [21]. Urethral striated muscle, which is called the rhabdosphincter or external urethral sphincter, plays an important role in urethral continence. Animal studies demonstrated that duloxetine increases the concentrations of both serotonin and NA in the sacral spinal cord region, leading to the stimulation of the rhabdosphincter activity, thus preventing urine leakage [22]. Recently, significant improvement of urinary incontinence was demonstrated in patients who were treated with myoblasts and autologous stem cells injected into the rhabdosphincter in the female urethra, demonstrating its crucial role in urinary continence [23]. The control of the adrenergic (sympathetic), cholinergic (parasympathetic) and nonadrenergic-noncholinergic (NANC) mechanisms on urethral smooth muscle tone (intraurethral pressure) is critical for the maintenance of urinary continence [24].

\section{Adrenergic Pathways}

\section{$\alpha$-Adrenoceptors}

Closure of the bladder neck and urethra depends on the adrenergic system to some extent (fig. 2) [25]. Urodynamic studies demonstrated that $\alpha$-adrenoceptors (ARs) maintain almost $50 \%$ of the intraurethral pressure in humans $[26,27]$. The $\alpha_{1}$-AR subtype is the predominating postjunctional $\alpha$-AR in the human urethral smooth muscle (fig. 3) [28]. NA (both $\alpha_{1^{-}}$and $\alpha_{2}$-AR agonist), not clonidine $\left(\alpha_{2}\right.$-AR agonist), produced concentration-de- 
Fig. 2. Second-messenger systems in the urethral smooth muscle cell. Ach = Acetylcholine; $\mathrm{NE}=$ norepinephrine; $\mathrm{PL}-\mathrm{C}=$ phospholipase $\mathrm{C}$; $\mathrm{IP}_{3} / \mathrm{DAG}=$ inositol triphosphate/diacylglycerol; $\mathrm{SR}=$ sarcoplasmic reticulum; $\mathrm{AC}=$ adenylate cyclase. $\mathrm{M}_{2}$, $\mathrm{M}_{3}$ and $\beta$-receptors are coupled to $\mathrm{G}$ proteins. $+=$ Stimulation; $-=$ inhibition.

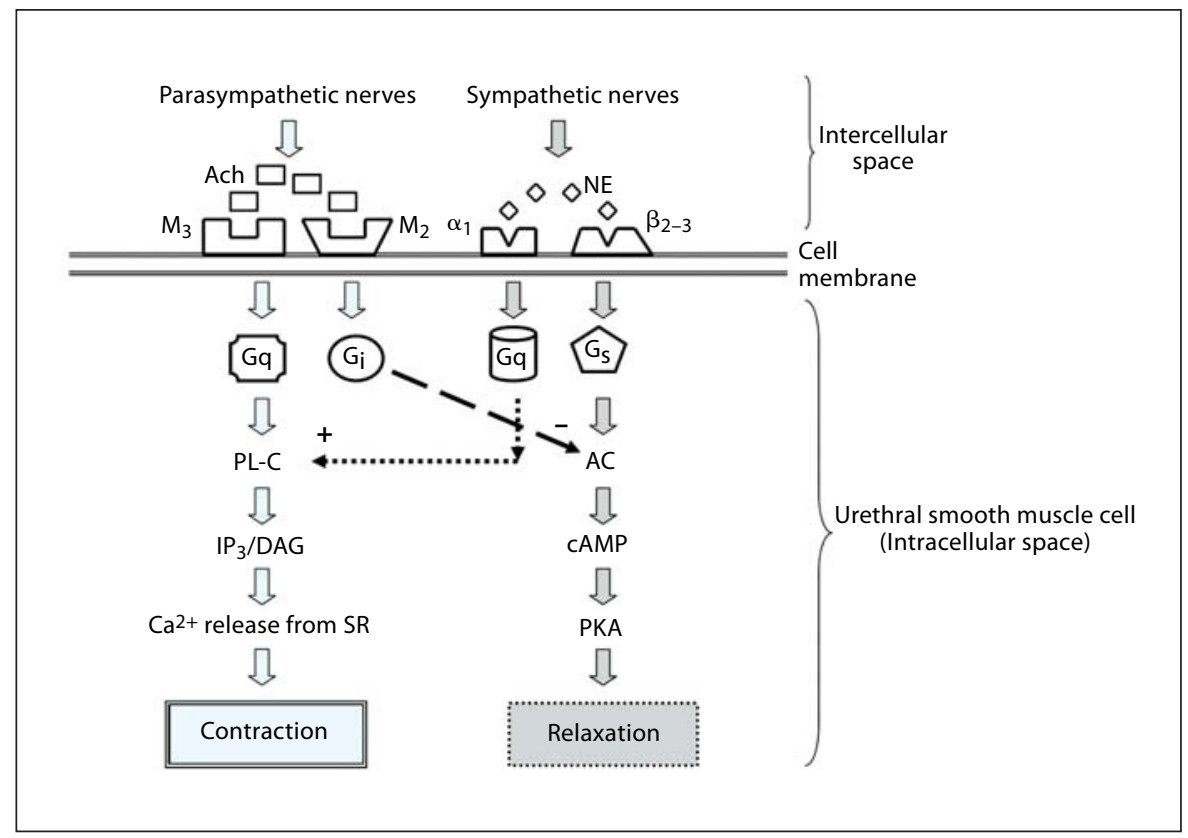

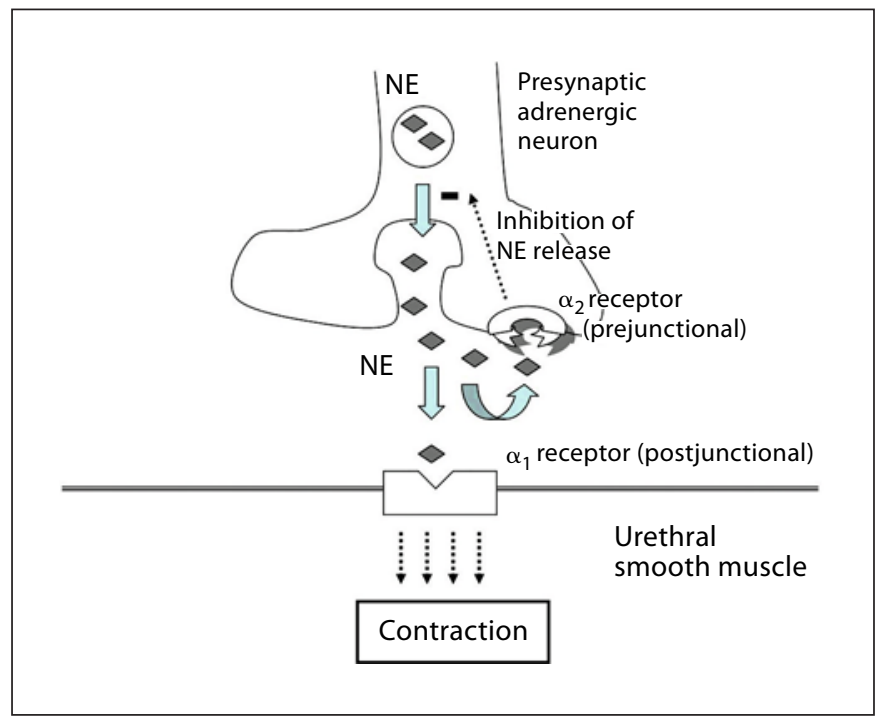

Fig. 3. Mechanism of action of $\alpha$-adrenoceptors in the human female urethral smooth muscle cell.

pendent contractions in all urethral levels in the females. These contractions were most intense in mid to proximal urethra. Sympathetic nerves acting via $\alpha_{1}$-ARs seem to be the principal mechanism maintaining resting urethral tonus (fig. 2, 3) [29]. Three $\alpha_{1}$-AR subtypes $\left(\alpha_{1 \mathrm{a} / \mathrm{A}}, \alpha_{1 \mathrm{~b} / \mathrm{B}}\right.$, $\left.\alpha_{1 d / D}\right)$ have been detected and $\alpha_{1 \mathrm{a} / \mathrm{A}}$ is found to be the pre- dominating receptor in the human lower urinary tract $[30,31]$. The role for $\alpha_{1 L}$-Ars, a distinct conformational state of the $\alpha_{1 \mathrm{a} / \mathrm{A}}$-ARs, has also been proposed [32]. Discovery of a selective urethral $\alpha_{1}$-AR subtype agonist has important clinical significance, because this agent might be used in the treatment of urinary incontinence in women. Although low levels of $\alpha_{1 \mathrm{~d} / \mathrm{D}}$-AR mRNA was detected in the female urethra, $\alpha_{1 b / B}-A R$ mRNA was not identified [33]. $\alpha_{2}$-ARs regulate the release of NA from adrenergic nerves in the urethra (fig. 3) [25]. Notably, clonidine was demonstrated to decrease intraurethral pressure in humans. This effect might be either due to effects on adrenergic nerve terminals or central nervous system leading to a decrease in peripheral sympathetic nervous activity [34]. In the guinea pig urethra, the prejunctional $\alpha_{2 \mathrm{~A}}$ subtype was suggested to be responsible for the secretion of NA. However, the release of other currently unknown mediator(s) might also act through $\alpha_{2}$-ARs and warrants further research [35]. A recent study showed that $\alpha_{1 L}$-ARs mediate smooth muscle contraction of the female pig urethra. This mechanism seems to be responsible for contraction of the longitudinal and circular urethral muscle, thus maintaining the sympathetic control of intraurethral pressure and continence [36].

\section{$\beta$-Adrenoceptors}

Bladder response to norepinephrine (NE) presents with two distinct characteristics: relaxation via $\beta$-ARs in 
the body of the bladder (fig. 2) [37, 38], and contraction mediated via $\alpha$-ARs in the bladder base and urethra (fig. 2, 3) $[24,30,39-41]$. Although $\beta_{2}$-ARs were detected in the human bladder neck [42], $\beta_{3}$-ARs predominated in the human bladder [43]. Administration of $\beta_{2}$-AR agonists reduced intraurethral pressure in humans, but $\beta$-AR antagonists did not have similar acute effects [44]. However, blockage of $\beta$-ARs might increase urethral tone by enhancing the effects of NA on $\alpha$-ARs. This effect might prove a role for SUI treatment [45]. On the other hand, clenbuterol (a selective $\beta_{2}$-AR agonist) was shown to increase maximal urethral pressure [46]. Clinical improvement in patients with stress incontinence by clenbuterol was suggested to occur due to its action on urethral striated and/or pelvic floor muscles [37, 47].

$\beta$-ARs were suggested to cause cyclic adenosine monophosphate (cAMP)-mediated smooth muscle relaxation and muscarinic receptor stimulation $\left(\mathrm{M}_{2}\right)$ by indirectly inhibiting cAMP formation [48]. In dogs, $\beta 2$ stimulants were demonstrated to increase the contractility of fatigued urethral sphincter [49]. $\beta$-ARs mediate relaxation through $\beta_{1^{-}}, \beta_{2^{-}}$or $\beta_{3}$-receptors and they have been shown in the bladder and urethra in several species including humans $[39,50]$. In the pig urethra, $\beta_{2^{-}}$and $\beta_{3^{-}}$ ARs were demonstrated to mediate relaxation in response to isoproterenol ( $\beta$-AR agonist) [51]. In the human urethra, radioligand-binding studies demonstrated the presence of $\beta_{2}$ and $\beta_{3}$-AR subtypes. Therefore, agents acting via these receptors might have a promising role in the management of urinary incontinence in women [27].

\section{Cholinergic Pathways}

\section{Muscarinic Receptors}

Urethral smooth muscle receives a rich cholinergic innervation $[52,53]$. Muscarinic receptors $\left(\mathrm{M}_{2}\right.$ and $\left.\mathrm{M}_{3}\right)$ seem to be acting for the contraction of the bladder base and urethra (fig. 2) $[24,30,54]$. Although the $\mathrm{M}_{2}$ subtype is predominating in number in the urinary bladder [55, 56], $\mathrm{M}_{3}$ receptors are mainly responsible for contraction $[57,58]$. Four subtypes of muscarinic receptos $\left(M_{1}, M_{2}\right.$, $\mathrm{M}_{3}$ and $\mathrm{M}_{4}$ ) have been demonstrated in the rat bladder [59] and $M_{1}, M_{2}$ and $M_{3}$ receptors were shown to cause contraction in the rabbit urethra $[60,61]$. On the other hand, pig urethra appears to have predominantly $\mathrm{M}_{2}$ receptors. Contraction of the pig urethra was demonstrated to be predominantly mediated by $\mathrm{M}_{2}$ and $\mathrm{M} 3$ receptors in the circular muscle and only by $\mathrm{M}_{3}$ receptors in the longitudinal muscle [48]. Stimulation of the muscarinic receptors on the urethral smooth muscle was demonstrated to cause contraction in humans mainly in the longitudinal layer [25]. In an experimental study using female human urethral tissues, acetylcholine contracted only proximal urethra and bladder neck [29]. Tolerable doses of cholinergic agonist administration did not have any significant effect on intraurethral pressure in humans [62]. Carbachol (cholinergic agonist) inhibits release of NE from adrenergic nerve and Ach from cholinergic nerve terminals by acting upon prejunctional muscarinic receptors, hence decreasing urethral tone and intraurethral pressure (fig. 4) [63]. $\mathrm{M}_{2}$ receptors are involved in the contraction of the smooth muscle via the following mechanisms: (1) inhibition of cyclic adenosine monophosphate (cAMP) mediated smooth muscle relaxation by $\beta$-adrenoceptors (fig. 2) [55], (2) opening of nonspecific cation channels, thereby leading to cellular depolarization and calcium influx into the cell $[64,65]$, and (3) under pathologic conditions such as denervation or neurogenic dysfunction [66, 67]. The muscarinic receptor subtypes in the human urethra that cause contraction are not currently well established. This area warrants further research in order to explore the role for use of selective muscarinic agents in the treatment of female urinary incontinence.

\section{Nonadrenergic, Noncholinergic (NANC) Pathways}

During voiding, urethral relaxation and detrusor contraction occurs simultaneously [68]. Factors contributing to urethral relaxation can be summarized as follows: (1) presynaptic muscarinic receptor stimulation (inhibition of NE release causes decreased proximal urethral tone) (fig. 4), (2) longitudinal urethral smooth muscle contraction due to muscarinic stimulation (resultant urethral shortening and widening decreases intraurethral pressure) (fig. 2), and (3) NANC mechanisms (explained below).

\section{Nitric Oxide (NO)}

L-Arginine-derived NO was shown to be present in the urothelium and afferent nerves [69] which appeared to be the major NANC inhibitory transmitter in the LUT [70, 71]. Its main effect was proximal urethral relaxation [7276]. Nitric oxide synthase (NOS) is responsible for $\mathrm{NO}$ synthesis and has calcium-dependent and calcium-independent isoforms. The calcium-dependent form has 2 isoforms: endothelial and neuronal NOS [77]. Neuronal NOS (nNOS) was demonstrated in the urethral muscle 
Fig. 4. Cholinergic and adrenergic innervation of the human urethral smooth muscle cell. Ach = Acetylcholine.
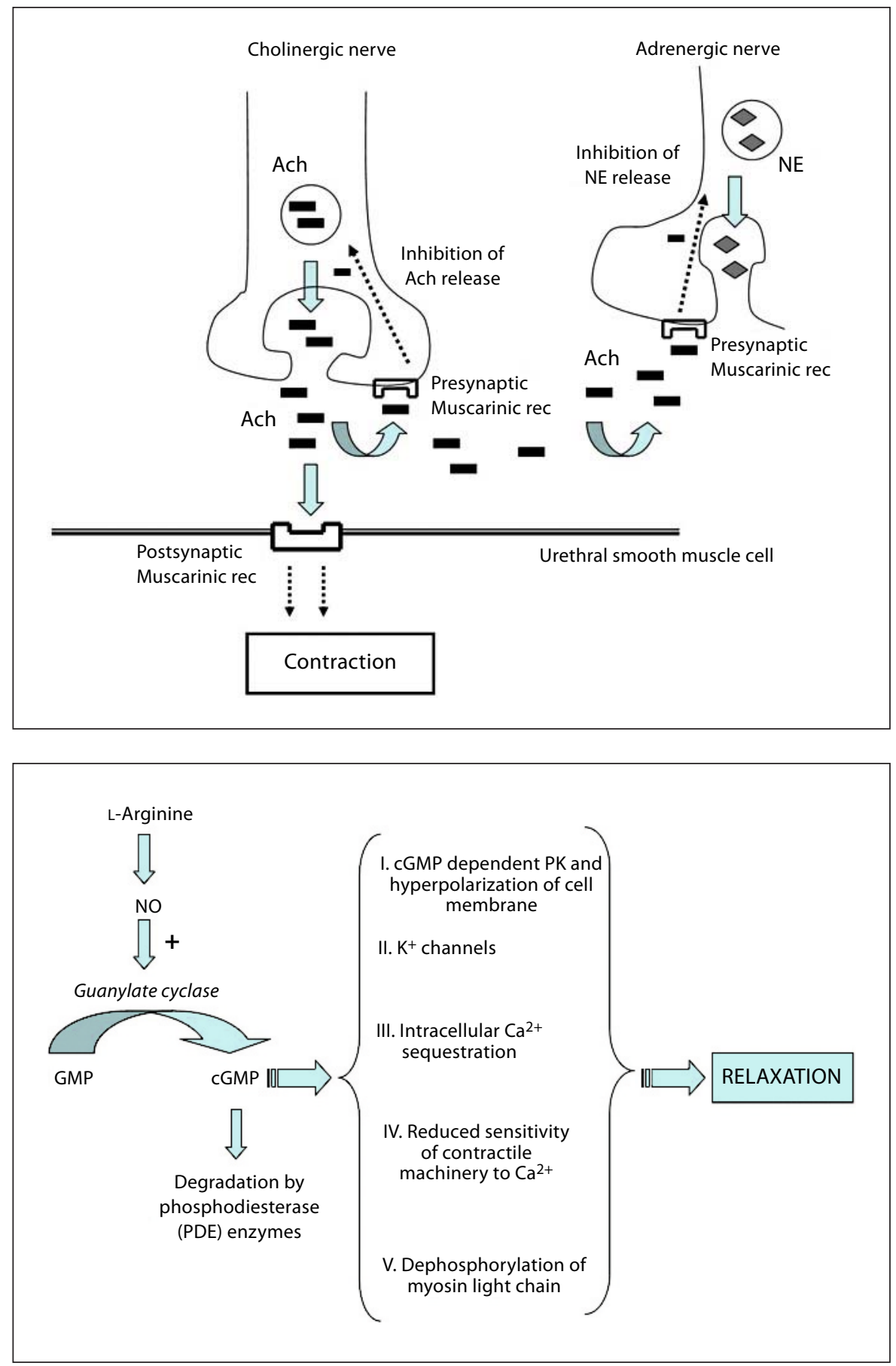

Fig. 5. Mechanisms involved in smooth muscle relaxation due to CGMP production in the female urethra. cGMP = Cyclic guanosine-monophosphate; $\mathrm{PK}=$ protein kinase; $\mathrm{NO}=$ nitric oxide + = stimulation. and lamina propria, whereas endothelial NOS (eNOS) was detected in the urothelium and endothelium of submucosal blood vessels $[78,79]$. NO activates guanylate cyclase producing cyclic guanosine monophosphate (cGMP) and this leads to smooth muscle relaxation [80]. Mechanisms involved in smooth muscle relaxation based on cGMP production are summarized in figure 5 [81-85]. cGMP has been detected in the urothelium and submucosa of the urethra $[79,86]$ and NOS and soluble guanylate cyclase activities have been demonstrated in the urethral mucosa and smooth muscle [87]. The presence of phosphodiesterase type 5 (PDE-5) and cGMP has been 


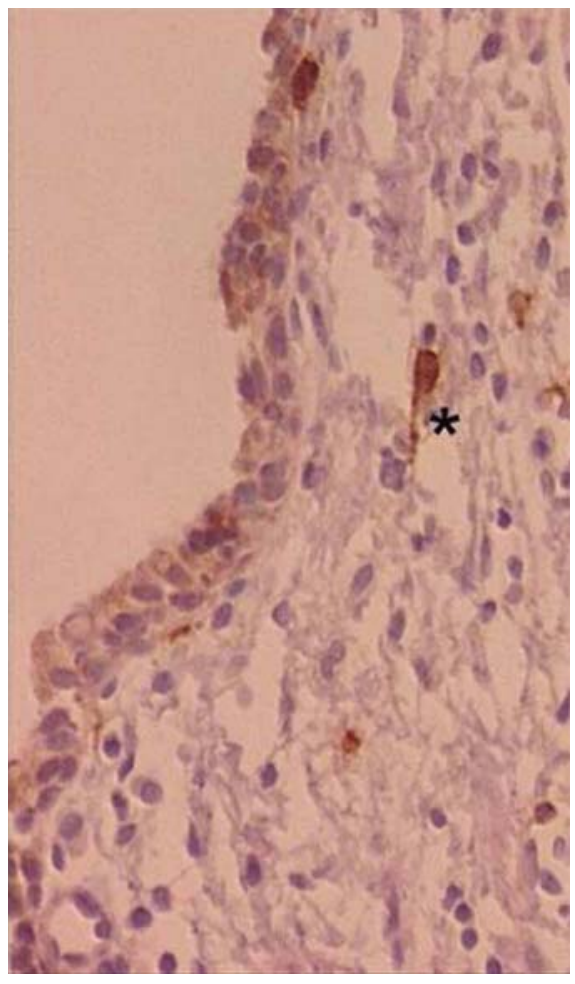

Fig. 6. c-kit-positive interstitial cells $\left({ }^{*}\right)$ with a fusiform cell body and dendritic processes in the human urethral suburothelium. Courtesy of Dokuz Eylül University School of Medicine, Department of Pathology, Izmir, Turkey.

shown in the female urethra. Inhibition of PDE-5 with drugs like sildenafil, vardenafil and tadalafil caused $\mathrm{NO} /$ cGMP-mediated relaxation [88].

Recently, c-kit (CD117)-positive interstitial cells have been demonstrated in the urinary tract (i.e. urethra). These cells formed a network immunoreactive for GMP and have been suggested to function as a pacemaker in the regulation of urethral tone $[89,90]$. We also demonstrated these cells in the human bladder and urethra (see fig. 6) and are currently investigating their role in lower urinary tract symptoms in women [unpubl. data].

\section{Adenosine Triphosphate (ATP)}

Adenosine, adenosine diphosphate (ADP) and ATP are extracellular purines which are involved in cellular signaling via cell-surface receptors (fig. 7) [91-96]. It has been shown that ATP is released with electric field stimulation and mechanical stretch of the bladder. However, the contribution of ATP release from neuronal sources is much lower compared to nonneuronal sources (urothelium) [97]. ATP is believed to cause smooth muscle relaxation via

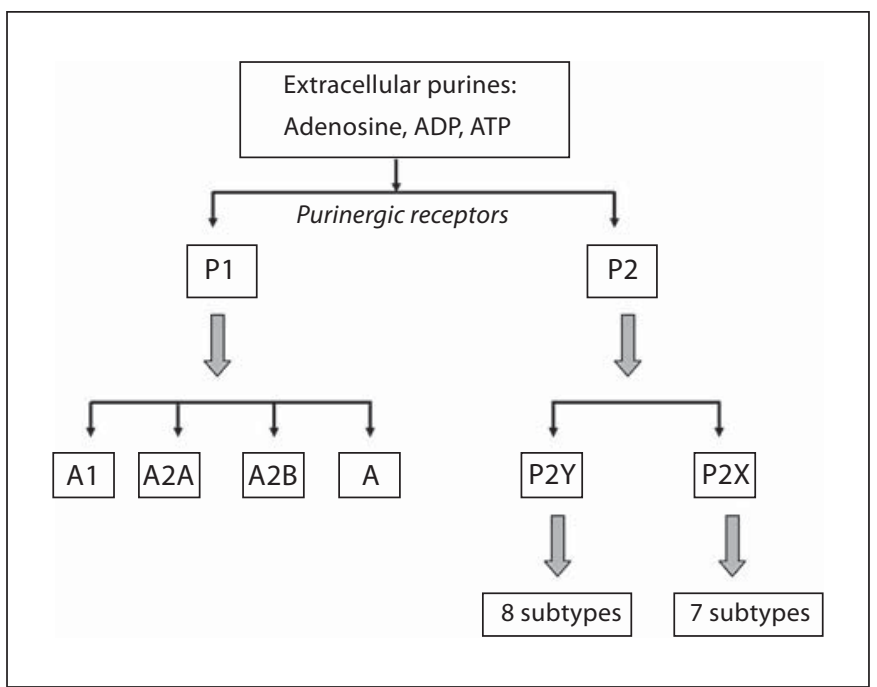

Fig. 7. Purinergic receptors and their subtypes. $\mathrm{ADP}=$ Adenosine diphosphate; ATP = adenosine triphosphate.

G-protein-coupled P2Y receptors [98] and activation of cAMP-dependent protein kinase A [99]. ATP was demonstrated to cause urethral smooth muscle relaxation in various species such as pigs [100, 101], guinea pigs [102], rabbits [103] and hamsters [104]. The pharmacologic effects of ATP and other purines on the human female urethra are not very clear and need further scientific attention.

\section{Carbon Monoxide (CO)}

Heme oxygenase-1 (HO-1) and HO-2 (present in the nerve fibers located in the LUT and urethra of the pigs) are the two enzymes responsible for CO production [100]. $\mathrm{CO}$ was shown to cause relaxation of the urethra via cGMP in pigs (see fig. 5 for actions of cGMP in the urethral smooth muscle) [100]. Furthermore, immunoreactivity for HO-2 was demonstrated in neuronal structures innervating the male and female urethral sphincters [105]. Clearly, functional impact of CO on the urethra is another area for exploration.

\section{Neuropeptides}

Vasoactive intestinal polypeptide (VIP), neuropeptide Y (NPY), tachykinins and endothelins are neuropeptides that are shown to be involved in urethral contraction and relaxation mechanisms similar to the urinary bladder [5].

VIP

VIP-positive nerves have been demonstrated in the human urethra and various other species [25]. Although 
its effect on the human female urethra is unclear, VIP was shown to relax the isolated rabbit and guinea pig urethral strips $[106,107]$.

\section{NPY}

In the isolated female rabbit and rat urethra, NPY was demonstrated to have inhibitory effects $[108,109]$. However, the effect of NPY on human female urethra needs to be clarified by functional studies.

\section{Tachykinins}

Substance P (SP), neurokinin A (NKA), and neuroki$\operatorname{nin} \mathrm{B}(\mathrm{NKB})$ are tachykinins that are present in the afferent nerves of the lower urinary tract and act on NK1, NK2, and NK3 receptors [5]. Tachykinins were shown to cause urethral contraction in various species including humans [110-113], but their role in female urethral physiology remains elusive. The amount of peptide-containing (NPY, VIP and SP) nerve supply to the perineal muscles in patients with genitourinary prolapse with concomitant urinary incontinence was compared to that of healthy controls [114]. The density of these nerves was found to be significantly less in the latter group compared to the incontinent group, suggesting a possible role for tachykinins in female urinary continence mechanisms. Functional importance of tachykinins in the etiology of urethral instability has to be validated with future research.

\section{Endothelins}

Endothelin (ET) receptors were shown in the urethral smooth muscle and urothelium in various animals [115117]. ET-1 subtype was demonstrated to cause urethral smooth muscle contractions via ET-A receptors in the rabbit $[118,119]$. However, human studies regarding endothelins and urethral function are lacking.

\section{Prostanoids}

Prostanoids [prostaglandins (PG) and thromboxanes (TX)] are synthesized by cyclooxygenase (COX) enzymes [5]. In the human female urethra, $\mathrm{PGF}_{2 \alpha}$ leads to contraction [120], whereas $\mathrm{PGE}_{1}$ and $\mathrm{PGE}_{2}$ cause relaxation [25] leading to a decrease in the maximum urethral pressure and reduction in the urethral closure pressure. In addition, intravesical $\mathrm{PGE}_{2}$ administration was shown to decrease the urethral closure pressure in healthy women [121].

\section{5-Hydroxytryptamine (5-HT, Serotonin)}

Onuf's nucleus is located in the sacral spinal cord. Motor neurons present in Onuf's nucleus have dense populations of noradrenergic and serotonergic terminals that control urethral function. Animal studies have shown that $\alpha_{1}$-adrenoceptors and serotonin receptors in Onuf's nucleus facilitate sphincter contraction [122]. 5-HT and NA were suggested to function as modulatory neurotransmitters in the excitation of motor neurons controlling rhabdosphincter activity in the presence of glutamate [22].

Duloxetine hydrochloride is a balanced serotonin and NE reuptake inhibitor and functions acting on Onuf's nucleus. Serotonin and NE activate the pudendal motor neurons in Onuf's nucleus and enhance the strength of urethral sphincter contractions [123-127]. In phase III $[128,129]$ clinical trials, duloxetine was found to be efficient and tolerable in the treatment of SUI in women. However, nausea was the most common side effect. Duloxetine $80 \mathrm{mg} /$ day (40 mg twice daily) was suggested to be the optimum dose in women with SUI [127]. Moreover, duloxetine was shown to have a significant effect on the excitability of pudendal motor neurons and urethral sphincter contractility in a urodynamic study conducted in healthy women [130].

Although duloxetine has been approved for treatment of SUI in Europe, pharmaceutical companies withdrew their applications to Food and Drug Administration (FDA) in 2005 because of manufacturers' failure to demonstrate the drug's positive risk-benefit ratio.

\section{Rho-Kinase}

Circular smooth muscle in the urethra exhibits spontaneous tone that maintains urinary continence and its relaxation during micturition is necessary for voiding [131]. Rho-kinase modulates the smooth muscle contraction via phosphorylation of myosin light chain [132]. Activation of Rho-kinase inhibits smooth muscle myosin phosphatase, leading to $\mathrm{Ca}^{2+}$ sensitization of the smooth muscle, thus causing contraction of the muscle [133] (fig. 8). It has recently been demonstrated that female pig urethral tone is dependent on Rho-guanosine triphosphatase and Rho-associated kinase [134]. The significance of Rho-kinase pathway in the contraction and relaxation of human female urethra needs to be investigated.

\section{Effects of Hormones on Urethral Function}

Estrogen receptors are mainly detected in the squamous epithelium of bladder trigone and proximal and distal urethra rather than urothelium of the female lower urinary tract. In contrast, progesterone receptor expression was shown to vary in the female urinary tract [135]. Squamous epithelium of the female LUT was shown to express greater levels of cell proliferation in estrogen-re- 
plete compared to estrogen-deficient women [136]. Several beneficial effects of estrogen on female LUT were reported. Mainly, increased urothelium thickness, increased number of adrenergic receptors and increased sensitivity in urethral smooth muscle increase urethral sphincter tonus $[137,138]$. In addition, sympathetic neurons were demonstrated to express estrogen $\alpha$ - and $\beta$-receptors in the female rat proximal urethra [139]. A recent report suggested that 3-month oral and vaginal estrogen therapy significantly decreased the incidence of urinary frequency and nocturia in hysterectomized postmenopausal women with almost $73 \%$ subjective improvement of stress incontinence in the oral group and $60 \%$ in the topical group [140]. On the other hand, conjugated equine estrogen (CEE) alone and CEE in combination with medroxyprogesterone acetate (MPA) were suggested to increase the risk of urinary incontinence among continent women [141]. Although the use of estrogen and progesterone supplementation for more than 3 months in postmenopausal women suffering from SUI has been accepted as a common clinical practice before proceeding with more invasive treatment modalities, a meta-analysis reviewing 23 trials on estrogen treatment in postmenopausal women failed to show promising evidence of clinical improvement in female patients suffering from SUI [142].

Androgen receptors were also demonstrated in the urethral and bladder epithelium of rabbits [143]. In the human embryos, epithelium of the urethral groove and mesenchyme of the urethral folds showed positive staining for androgen receptors [144]. However, the impact of androgens on female urethra is still under investigation.

Urinary incontinence is not a rare condition during pregnancy. Obviously, continence dysfunction is a result of anatomical and functional alterations in the bladder and urethra [145]. Although the anatomical changes regarding the urethra are established during pregnancy [146], alterations at the receptor and cellular levels need to be clarified.

\section{Sensory Function}

Sensory innervation of the urethra is conveyed to the spinal cord mainly via the pelvic nerve and dorsal root ganglia and to some extent via the hypogastric nerve [19]. The sensory nerves innervating the rhabdosphincter run through the pudendal nerve to the sacral spinal cord region [19]. Histopathologically, sensory nerves are identified by their sensory neuropeptide contents such as calcitonin gene-related peptide (CGRP), substance P (SP)

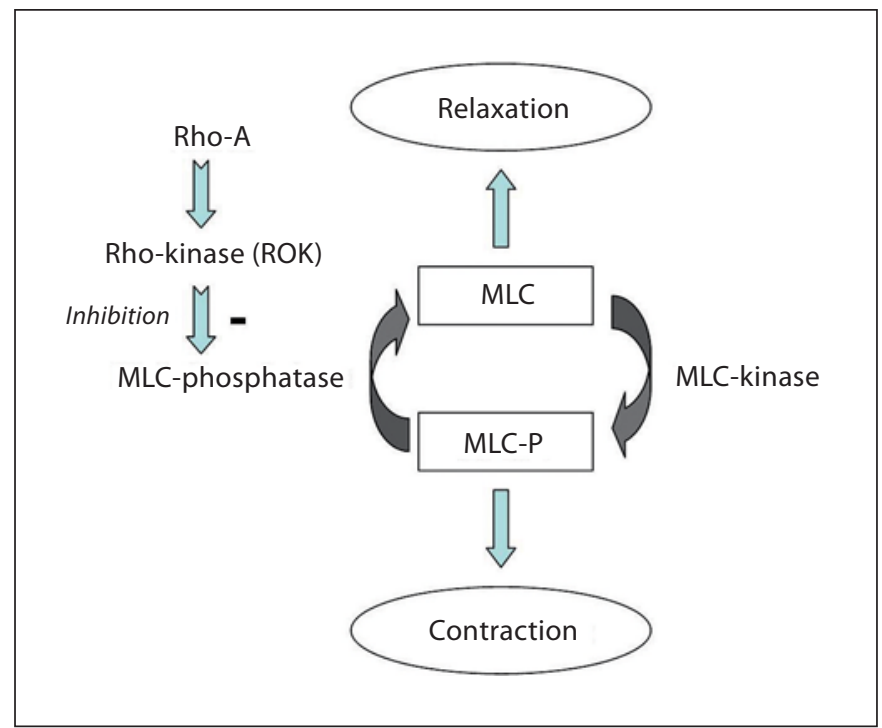

Fig. 8. Mechanism of action of Rho-kinase system in the female urethra. $\mathrm{ROK}=$ Rho-kinase $\mathrm{MLC}=$ myosine light chain .

and tachykinins [19]. Sensory function of the urethra is summarized in figure 9. Purinergic $\left(\mathrm{P}_{2} \mathrm{X}_{1-3}\right)$, vanilloid $\left(\mathrm{VR}_{1}\right)$, prostanoid (EP, TP) and neurokinin $\left(\mathrm{NK}_{2}\right)$ receptors have been demonstrated to be located on sensory afferent nerves [5] (fig. 9).

Afferent C-fibers were suggested to be specific sensory fibers specifically related with pain perception (nociception) and they were also shown to initiate a usually inactive, nonvoluntary, spinal micturition reflex [147, 148].

Vanilloid receptors on sensory nerves are activated by thermal and chemical noxious stimuli (temperatures $>43^{\circ} \mathrm{C}$ and $\mathrm{pH}$ levels $<6$ ) and it has been demonstrated that heat threshold for vanilloid receptor activation could be decreased to physiologic body temperatures by increasing $\mathrm{H}^{+}$concentration which is seen in inflammation, suggesting the role of vanilloid receptors in chronic inflammatory pain perception [5] (fig. 9).

After capsaicin or RTX binding, VR1 opens, allowing a massive $\mathrm{Ca}^{2+}$ and $\mathrm{Na}^{+}$inflow into the neuron leading to the arrest of voltage-sensitive $\mathrm{Ca}^{2+}$ conductance, disruption of metabolic pathways and release of neuropeptides $[149,150]$. Vanilloids were also shown to reduce nerve growth factor (NGF) in sensory neurons and prolonged NGF deprivation causes neuronal death [151].

It was shown that sensory innervation of the urethral mucosa is involved in inflammatory situations and administration of capsaicin can prevent noninfectious urethral inflammation [152]. Capsaicin (extracted from red 
Fig. 9. Sensory function of the urothelium. Sensory neurotransmitters released from the urothelium and sensory nerves due to mechanical stretch, inflammation or other disorders interact with the receptors on sensory nerve endings located on the suburothelium and muscle cells that might cause contraction, pain or stimulation of reflexes. NK = Neurokinin; NGF = nerve growth factor.

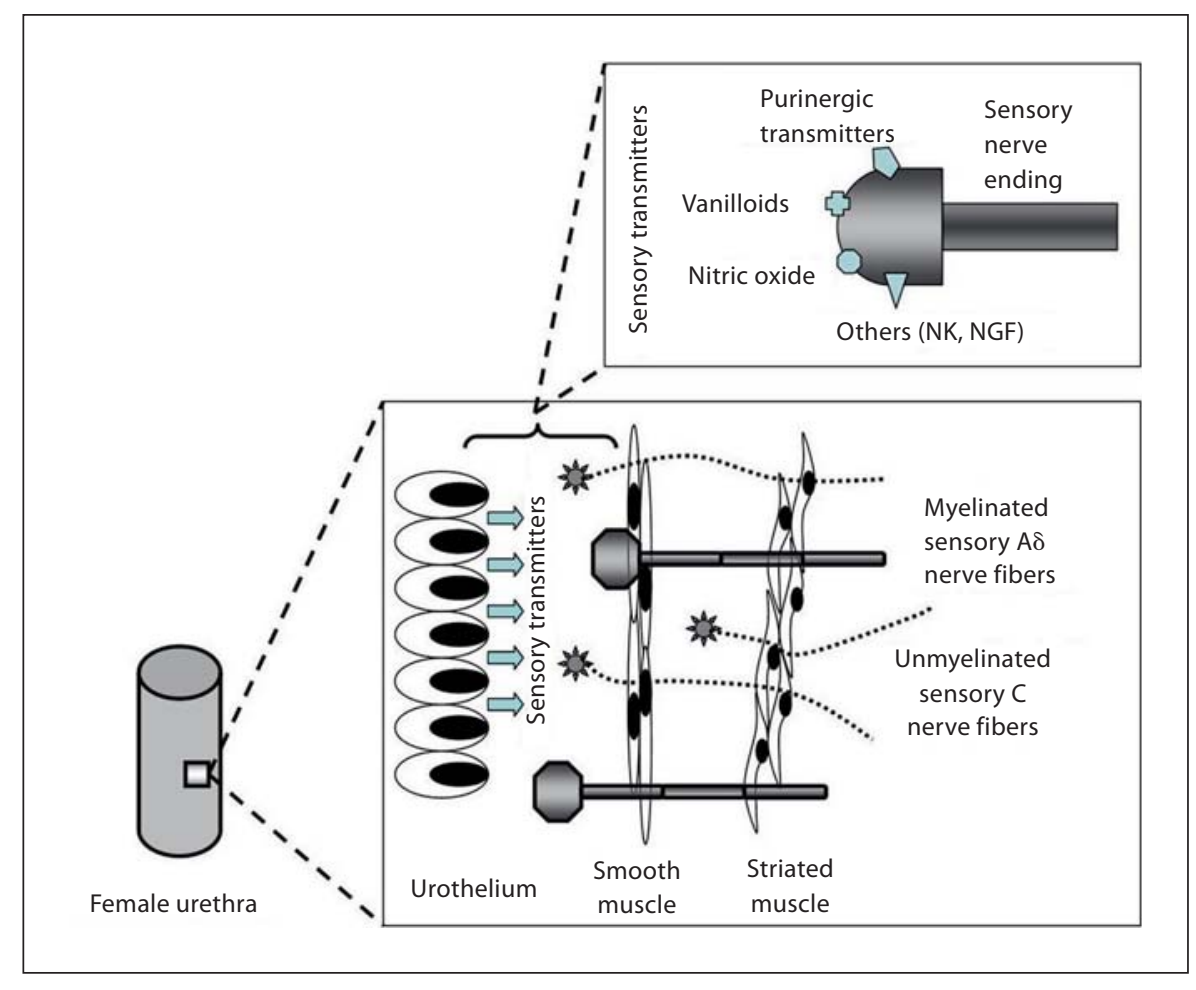

hot chili peppers) and resiniferatoxin (RTX) (extracted from Euphorbia resinifera) are the vanilloid substances that act via binding specific vanilloid receptors on the peripheral terminals of sensory afferents, nociceptive neurons which cause initially excitation then desensitization, and finally neurotoxicity [149].

De Laet et al. [153] determined current perception urethral thresholds (CPTs) by using neuroselective sinewave currents at $5 \mathrm{~Hz}$ (stimulating sensory C-fibers), 250 $\mathrm{Hz}$ (stimulating sensory A-delta-fibers), and 2,000 Hz (stimulating sensory A-beta-fibers) in the bladder, posterior, and the distal urethra in young healthy volunteer females. They found that bladder CPTs were significantly higher compared with CPTs in the posterior urethra and in the distal urethra. They did not find any significant difference between the posterior and distal urethra. Kinn et al. [154] also investigated CPTs by using an electrical stimulator connected to a urethral catheter in female patients. They found that CPTs were higher in old than in younger patients and no significant differences in sensitivity between patient groups with stress incontinence, urge, or mixed symptoms were detected. Recently, Kessler et al. [155] investigated the impact of radical pelvic surgery on urethral sensory thresholds in women. They found out that proximal urethral sensory thresh- olds were increased; however, distal urethral sensory thresholds did not change after radical pelvic surgery. These findings suggest that proximal urethral afferent nerve fibers run through the pelvic plexus in major which are likely to be injured during radical pelvic surgery. On the other hand, afferent innervation of the distal urethra is supplied by the pudendal nerve.

In conclusion, several pathways and receptors are involved in the contraction and relaxation of the human female urethra. Adrenergic system ( $\alpha$ - and $\beta$-ARs), cholinergic system (muscarinic receptors), NANC pathways and mediators such as NO, ATP, neuropeptides, prostanoids, serotonin and Rho-kinase are believed to play important roles in the physiology of the urethral function. Insufficient urethral closure and function might lead to SUI formation in women. Although the adrenergic system seems to be playing a major role in urethral contraction, management of SUI by $\alpha$-AR agonist administration has not been successful. Likewise, NO seems to be the major urethral relaxant, but the role of other transmitters in urethral contraction and relaxation needs further research. Understanding these mechanisms at the cellular and receptor level will possibly lead to the discovery of new drugs for use in the treatment of SUI and/or lower urinary tract symptoms in women. 


\section{References}

1 Resnick NM: Urinary incontinence. Lancet 1995;346:94-99.

-2 van der Vaart CH, de Leeuw JR, Roovers JP, et al: The effect of urinary incontinence and overactive bladder symptoms on quality of life in young women. BJU Int 2002;90:544549.

- 3 Cetinel B, Demirkesen O, Tarcan T, et al: Hidden female urinary incontinence in urology and obstetrics and gynecology outpatient clinics in Turkey: what are the determinants of bothersome urinary incontinence and help-seeking behavior? Int Urogynecol J Pelvic Floor Dysfunct 2007;18:659-664.

4 Tanagho EA, Miller ER: Initiation of voiding. Br J Urol 1970;42:175-183.

5 Canda AE, Cross RL, Chapple CR: Pharmacology of the lower urinary tract and management of overactive bladder. J Turkish German Gynecol Assoc 2006;7:146-158.

6 Madersbacher H: Neurourology and pelvic floor dysfunction. Minerva Ginecol 2004; 56:303-309.

7 Wells M: Continence following childbirth. Br J Nurs 1996;5:353-354.

-8 Kölbl H: Pregnancy, childbirth and the pelvic floor. Zentralbl Gynakol 2001;123:666671.

\9 Wong MY, Harmanli OH, Agar M, Dandolu V, Grody MH: Collagen content of nonsupport tissue in pelvic organ prolapse and stress urinary incontinence. Am J Obstet Gynecol 2003;189:1597-1599.

10 Elser DM, Fantl JA: Pelvic relaxation of the anterior compartment. Curr Opin Obstet Gynecol 1993;5:446-451.

11 Baessler K, Bircher MD, Stanton SL: Pelvic floor dysfunction in women after pelvic trauma. BJOG 2004;111:499-502.

12 Konstantinos H, Eleni K, Dimitrios H: Dilemmas in the management of female stress incontinence: the role of pelvic floor muscle training. Int Urol Nephrol 2006;38:513525.

13 Harvey MA: Pelvic floor exercises during and after pregnancy: a systematic review of their role in preventing pelvic floor dysfunction. J Obstet Gynaecol Can 2003;25:451453.

14 Perucchini D, DeLancey JO, Ashton-Miller JA, et al: Age effects on urethral striated muscle. II. Anatomic location of muscle loss. Am J Obstet Gynecol 2002;186:356-360.

15 De Groat WC: Spinal cord projections and neuropeptides in visceral afferent neurons. Prog Brain Res 1986;67:165-187.

16 Janig W, Morrison JF: Functional properties of spinal visceral afferents supplying abdominal and pelvic organs, with special emphasis on visceral nociception. Prog Brain Res 1986; 67:87-114.

17 de Groat WC, Downie JW, Levin RM, et al: Basic Neurophysiology and Neuropharmacology. New York, Lange, 2000, pp 457-488.
18 de Groat WC, Fraser MO, Yoshiyama M, et al: Neural control of the urethra. Scand J Urol Nephrol Suppl 2001;207:35-43.

19 Lincoln J, Burnstock G: Autonomic innervation of the urinary bladder and urethra; in Maggi CA (ed): The Autonomic Nervous System. Chapter 2. Nervous Control of the Urogenital System. London, Harwood Academic Publisher, 1993, pp 33-68.

20 Barber MD, Bremer RE, Thor KB, et al: Innervation of the female levator ani muscles. Am J Obstet Gynecol 2002;187:64-71.

21 Haab F, Zimmern PE, Leach GE: Female stress urinary incontinence due to intrinsic sphincteric deficiency: recognition and management. J Urol 1996;156:3-17.

22 Schuessler B: What do we know about duloxetine's mode of action? Evidence from animals to humans. BJOG 2006;113(suppl 1):59.

23 Mitterberger M, Pinggera GM, Marksteiner $\mathrm{R}$, et al: Adult stem cell therapy of female stress urinary incontinence. Eur Urol 2008; 53:169-175.

24 Bridgewater M, MacNeil HF, Brading AF: Regulation of tone in pig urethral smooth muscle. J Urol 1993;150:223-228.

25 Andersson KE: Pharmacology of lower urinary tract smooth muscles and penile erectile tissues. Pharmacol Rev 1993;45:253308.

26 Appell RA, England HR, Hussell AR, et al: The effects of epidural anesthesia on the urethral closure pressure profile in patients with prostatic enlargement. J Urol 1980;124:410411.

27 Furuya S, Kumamoto Y, Yokoyama E, et al: $\alpha$-Adrenergic activity and urethral pressure in prostatic zone in benign prostatic hypertrophy. J Urol 1982;128:836-839.

28 Brading AF, McCoy R, Dass N: $\alpha 1$-Adrenoceptors in urethral function. Eur Urol 1999; 36(suppl 1):74-79.

29 Taki N, Taniguchi T, Okada K, et al: Evidence for predominant mediation of $\alpha 1$-adrenoceptor in the tonus of entire urethra of women. J Urol 1999;162:1829-1832.

-30 Andersson KE: Neurotransmission and drug effects in urethral smooth muscle. Scand J Urol Nephrol Suppl 2001;207:26-34.

31 Daniels DV, Gever JR, Jasper JR, et al: Human cloned $\alpha 1 \mathrm{~A}$-adrenoceptor isoforms display $\alpha 1$-L-adrenoceptor pharmacology in functional studies. Eur J Pharmacol 1999; 370:337-343.

- 32 Ford AP, Daniels DV, Chang DJ, et al: Pharmacological pleiotropism of the human recombinant alphal-adrenoceptor: implications for alpha1-adrenoceptor classification. Br J Pharmacol 1997;121:1127-1135.
33 Nasu K, Moriyama N, Fukasawa R, et al: Quantification and distribution of alpha1adrenoceptor subtype mRNAs in human proximal urethra. Br J Pharmacol 1998;123: 1289-1293.

- 34 Nordling J, Meyhoff HH, Christensen NJ: Effects of clonidine (Catapresan) on urethral pressure. Invest Urol 1979;16:289-291.

35 Alberts P: Subtype classification of the presynaptic $\alpha$-adrenoceptors which regulate $\left[{ }^{3} \mathrm{H}\right]$ noradrenaline secretion in guinea-pig isolated urethra. Br J Pharmacol 1992;105: 142-146.

36 Bagot K, Chess-Williams R: Alpha1A/L-adrenoceptors mediate contraction of the circular smooth muscle of the pig urethra. Auton Autacoid Pharmacol 2006;26:345-353.

37 Morita T, Iizuka H, Iwata T, et al: Function and distribution of beta 3 -adrenoceptors in rat, rabbit and human urinary bladder and external urethral sphincter. J Smooth Muscle Res 2000;36:21-32.

38 Hudman D, Elliott RA, Whitaker P, et al: Inhibition of the contractile responses of isolated human and rat bladders by clenbuterol. J Urol 2001;166:1969-1973.

39 Levin RM, Wein AJ: Quantitative analysis of alpha and beta adrenergic receptor densities in the lower urinary tract of the dog and the rabbit. Invest Urol 1979;17:75-77.

40 Van der Werf BA, Creed KE: Mechanical properties and innervation of the smooth muscle layers of the urethra of greyhounds. BJU Int 2002;90:588-595.

41 Hashimoto S, Kigoshi S, Muramatsu I: Neurogenic responses of urethra isolated from the dog. Eur J Pharmacol 1992;213:117-123.

42 Levin RM, Ruggieri MR, Wein AJ: Identification of receptor subtypes in the rabbit and human urinary bladder by selective radioligand binding. J Urol 1988;139:844-848.

43 Takeda M, Obara K, Mizusawa T, et al: Evidence for $\beta_{3}$-adrenoceptor subtypes in relaxation of the human urinary bladder detrusor: analysis by molecular biological and pharmacological methods. J Pharmacol Exp Ther 1999;288:1367-1373.

44 Thind P, Lose G, Colstrup H, et al: The influence of $\beta$-adrenoceptor and muscarinic receptor agonists and antagonists on the static urethral closure function in healthy females. Scand J Urol Nephrol 1993;27:31-38.

45 Andersson KE, Appell R, Awad S, et al: Pharmacological treatment of urinary incontinence; in Abrams P, Khoury S, Wein A (eds): Incontinence, 1st International Consultation on Incontinence. Plymouth, Plymbridge Distributors Ltd, 2002, pp 479-512.

$\checkmark 46$ Yasuda K, Kawabe K, Takimoto Y, et al; the Clenbutrol Clinical Research Group: A double-blind clinical trial of a beta 2 -adrenergic agonist in stress incontinence. Int Urogynecol J 1993;4:146-151. 
-47 Morita T, Kihara K, Nagamatsu H, et al: Effects of clenbuterol on rabbit vesicourethral muscle contractility. J Smooth Muscle Res 1995;31:119-127.

-48 Yamanishi T, Chapple CR, Yasuda K, et al: The role of M2-muscarinic receptor subtypes mediating contraction of the circular and longitudinal smooth muscle of the pig proximal urethra. J Urol 2002;168:308-314.

49 Yamanishi T, Yasuda K, Tojo M, Hattori T, Sakakibara R, Shimazaki J: Effects of beta 2stimulants on contractility and fatigue of canine urethral sphincter. J Urol 1994;151: 1066-1069.

-50 Fujimura T, Tamura K, Tsutsumi T, et al: Expression and possible functional role of the beta3-adrenoceptor in human and rat detrusor muscle. J Urol 1999;161:680-685.

-51 Yamanishi T, Chapple CR, Yasuda K, et al: The functional role of beta-adrenoceptor subtypes in mediating relaxation of pig urethral smooth muscle. J Urol 2003;170:25082511.

-52 Andersson KE: New roles for muscarinic receptors in the pathophysiology of lower urinary tract symptoms. BJU Int 2000;86:3642.

53 Mattiasson A, Andersson KE, Andersson PO, et al: Nerve-mediated functions in the circular and longitudinal muscle layers of the proximal female rabbit urethra. J Urol 1990;143:155-160.

54 Yamanishi T, Chapple CR, Yasuda K, et al: The role of $\mathrm{M} 2$ muscarinic receptor subtypes in mediating contraction of the pig bladder base after cyclic adenosine monophosphate elevation and/or selective M3 inactivation. J Urol 2002;167:397-401.

-55 Yamanishi T, Chapple CR, Yasuda K, et al: The role of $\mathrm{M}$-muscarinic receptors in mediating contraction of the pig urinary bladder in vitro. Br J Pharmacol 2000;131:14821488 .

56 Wang P, Luthin GR, Ruggieri MR: Muscarinic acetylcholine receptor subtypes mediating urinary bladder contractility and coupling to GTP binding proteins. J Pharmacol Exp Ther 1995;273:959-966.

57 D’Agostino G, Bolognesi ML, Lucchelli A, et al: Prejunctional muscarinic inhibitory control of acetylcholine release in the human isolated detrusor: involvement of the M4 receptor subtype. Br J Pharmacol 2000;129: 493-500.

58 Sellers DJ, Yamanishi T, Chapple CR, et al: M3 muscarinic receptors but not M2 mediate contraction of the porcine detrusor muscle in vitro. J Auton Pharmacol 2000;20:171176.

-59 Braverman AS, Kohn IJ, Luthin GR, et al: Prejunctional M1 facilitatory and M2 inhibitory muscarinic receptors mediate rat urinary bladder contractility. Am J Physiol 1998;274:R517-523.
60 Mutoh S, Latifpour J, Saito M, et al: Evidence for the presence of regional differences in the subtype specificity of muscarinic receptors in rabbit lower urinary tract. J Urol 1997;157: 717-721.

61 Nagahama K, Tsujii T, Morita T, et al: Differences between proximal and distal portions of the male rabbit posterior urethra in the physiological role of muscarinic cholinergic receptors. Br J Pharmacol 1998;124:11751180.

62 Ek A, Andersson KE, Ulmsten U: The effects of norephedrine and bethanechol on the human urethral closure pressure profile. Scand J Urol Nephrol 1978;12:97-104.

63 Mattiasson A, Andersson KE, Sjogren C: Adrenoceptors and cholinoceptors controlling noradrenaline release from adrenergic nerves in the urethra of rabbit and man. J Urol 1984;131:1190-1195.

64 Nakamura T, Yagaguchi O, Kimura J: Muscarinic $\mathrm{M} 2$ receptors regulate $\mathrm{Ca}^{2+}$-activated $\mathrm{K}$ channels in bladder smooth muscle cells. Neurourol Urodyn 1998;17:400-407.

65 Hegde SS, Eglen RM: Muscarinic receptor subtypes modulating smooth muscle contractility in the urinary bladder. Life Sci 1999;64:419-428.

66 Braverman AS, Luthin GR, Ruggieri MR: M2 muscarinic receptor contributes to contraction of the denervated rat urinary bladder Am J Physiol 1998;275:R1654-R1660.

67 Braverman AS, Ruggieri MR, Pontari MA: The M2 muscarinic receptor subtype mediates cholinergic bladder contractions in patients with neurogenic bladder dysfunction. J Urol 2001;165:36-42.

68 Bradley WE: Neural control of urethrovesical function. Clin Obstet Gynecol 1978;21: 653-668.

69 Birder LA, Apodoca G, de Groat WC, et al: Adrenergic- and capsaicin-evoked nitric oxide release from urothelium and afferent nerves in urinary bladder. Am J Physiol 1998; 275:226-229.

70 Mumtaz FH, Khan MA, Thompson CS, et al: Nitric oxide in the lower urinary tract: physiological and pathological implications. BJU Int 2000;85:567-578.

71 Mamas MA, Reynard JM, Brading AF: Nitric oxide and the lower urinary tract: current concepts, future prospects. Urology 2003;61: 1079-1085.

72 Ehrén I, Iversen H, Jansson O, et al: Localization of nitric oxide synthase activity in the human lower urinary tract and its correlation with neuroeffector responses. Urology 1994;44:683-687.

73 Persson K, Alm P, Johansson K, et al: Nitric oxide synthase in pig lower urinary tract: immunohistochemistry, NADPH diaphorase histochemistry and functional effects. Br J Pharmacol 1993;110:521-530.

-74 Triguero D, Prieto D, Garcia-Pascual A: NADPH-diaphorase and NANC relaxations are correlated in the sheep urinary tract Neurosci Lett 1993;163:93-96.
75 Masuda H, Tsujii T, Okuno T, et al: Localization and role of nitric oxide synthase and endogenous nitric oxide synthase inhibitors in the rabbit lower urinary tract. J Urol 2002; 167:2235-2240.

76 Zygmunt PM, Zygmunt PK, Högestätt ED, et al: Effects of omega-conotoxin on adrenergic, cholinergic and NANC neurotransmission in the rabbit urethra and detrusor. Br J Pharmacol 1993;110:1285-1290.

$>77$ Förstermann U, Closs EI, Pollock JS, et al: Nitric oxide synthase isozymes: characterization, purification, molecular cloning, and functions. Hypertension 1994;23:11211131 .

78 Burnett AL, Calvin DC, Chamness SL, et al: Urinary bladder-urethral sphincter dysfunction in mice with targeted disruption of neuronal nitric oxide synthase model idiopathic voiding disorders in humans. Nat Med 1997;3:571-574.

79 Fathian-Sabet B, Bloch W, Klotz T, et al: Localization of constitutive nitric oxide synthase isoforms and the nitric oxide target enzyme soluble guanylyl cyclase in the human bladder. J Urol 2001;165:1724-1729.

80 Mayer B: Regulation of nitric oxide synthase and soluble guanylyl cyclase. Cell Biochem Funct 1994;12:167-177.

81 Robertson BE, Schubert R, Hescheler J, et al: cGMP-dependent protein kinase activates Ca-activated K-channels in cerebral artery smooth muscle cells. Am J Physiol 1993;265: 299-303.

82 Peng W, Hoidal JR, Farrukh IS: Regulation of $\mathrm{Ca}^{2+}$ activated $\mathrm{K}^{+}$channels in pulmonary vascular smooth muscle cells: role for nitric oxide. J Appl Physiol 1996;81:1264-1272.

83 Bolotina VM, Najibi S, Palacino JJ, et al: Nitric oxide directly activates calcium-dependent potassium channels in vascular smooth muscle. Nature 1994;368:850-853.

84 Koh SD, Campbell AC, Carl A, et al: Nitric oxide activates multiple potassium channels in canine colonic smooth muscle. J Physiol 1995;489:735-743

85 Warner T, Mitchell JA, Sheng H, et al: Effects of cyclic GMP on smooth muscle relaxation. Adv Pharmacol 1994;26:171-194.

86 Smet PJ, Jonavicius J, Marshall VR, et al: Distribution of nitric oxide synthase-immunoreactive nerves and identification of cellular targets of nitric oxide in guinea-pig and human urinary bladder by cGMP immunohistochemistry. Neuroscience 1996;71:337348.

87 Masuda H, Okuno T, Suzuki M, et al: Different distribution of nitric oxide synthase and soluble guanylyl cyclase activities in the detrusor and proximal urethra of the rabbit. J Urol 2002;168:2286-2290.

-88 Werkström V, Svensson A, Andersson KE, et al: Phosphodiesterase 5 in the female pig and human urethra: morphological and functional aspects. BJU Int 2006;98:414-423. 
89 Sergeant GP, Hollywood MA, McHale NG, et al: $\mathrm{Ca}^{2+}$ signalling in urethral interstitial cells of Cajal. J Physiol 2006;576:715-720.

90 Sergeant GP, Thornbury KD, McHale NG, et al: Characterization of norepinephrineevoked inward currents in interstitial cells isolated from the rabbit urethra. Am J Physiol Cell Physiol 2002;283:885-894.

-91 Burnstock G, Knight GE: Cellular distribution and functions of $\mathrm{P} 2$ receptor subtypes in different systems. Int Rev Cytol 2004; 240:31-304.

92 Ralevic V, Burnstock G: Receptors for purines and pyrimidines. Pharmacol Rev 1998;50:413-492.

93 Burnstock G: A basis for distinguishing two types of purinergic receptors; in Straub RW, Bolis L (eds): Cell Membrane Receptors for Drugs and Hormones: A Multidisciplinary Approach. New York, Raven Press, 1978, pp 107-118.

94 Feoktistov I, Biaggioni I: Adenosine A2B receptors. Pharmacol Rev 1997;49:381402.

95 Fredholm BB, Ijzerman AP, Jacobson KA, et al: International Union of Pharmacology. XXV. Nomenclature and classification of adenosine receptors. Pharmacol Rev 2001; 53:527-552.

-96 Burnstock G, Kennedy C: Is there a basis for distinguishing two types of $\mathrm{P} 2$-purinocep tors? Gen Pharmacol 1985;16:433-440.

-97 Kumar V, Chapple CR, Chess-Williams R: Characteristics of adenosine triphosphatase release from porcine and human nor mal bladder. J Urol 2004;172:744-747.

$\$ 98$ Dalziel HD, Westfall DP: Receptors for adenine nucleotides and nucleosides: subclassification, distribution and molecular characterization. Pharmacol Rev 1994;46:449466.

99 McMurray G, Dass N, Brading AF: Purinoceptor subtypes mediating contraction and relaxation of marmoset urinary bladder smooth muscle. Br J Pharmacol 1998;123: 1579-1586.

100 Werkström V, Persson K, Andersson KE: NANC transmitters in the female pig urethra - localization and modulation of release via $\alpha 2$-adrenoceptors and potassium channels. Br J Pharmacol 1997;121:16051612.

- 101 Werkström V, Andersson KE: ATP- and adenosine-induced relaxation of the smooth muscle of the pig urethra. BJU Int 2005;96:1386-1391.

102 Callahan SM, Creed KE: Electrical and mechanical activity of the isolated lower urinary tract of the guinea-pig. Br J Pharmacol 1981;74:353-358.

103 Ohnishi N, Park YC, Kurita T, et al: Role of ATP and related purine compounds on urethral relaxation in male rabbits. Int J Urol 1997;4:191-197.
104 Pinna C, Glass R, Knight GE, et al: Purineand pyrimidine-induced responses and P2Y receptor characterization in the hamster proximal urethra. Br J Pharmacol 2005; 144:510-518

105 Ho KM, Ny L, McMurray G, et al: Co-localization of carbon monoxide and nitric oxide synthesizing enzymes in the human urethral sphincter. J Urol 1999;161:19681972.

106 Sjögren C, Andersson KE, Mattiasson A: Effects of vasoactive intestinal polypeptide on isolated urethral and urinary bladder smooth muscle from rabbit and man. J Urol 1985;133:136-140.

107 Werkström V, Alm P, Persson K, et al: Inhibitory innervation of the guinea-pig urethra; roles of CO, NO, VIP. J Auton Nerv Syst 1998;74:33-42.

108 Sjögren C, Andersson KE, Andersson PO, et al: Different effects of neuropeptide $\mathrm{Y}$ on electrically induced contractions in the longitudinal and circular smooth muscle layers of the female rabbit urethra. Acta Physiol Scand 1988;133:177-181.

109 Zoubek J, Somogyi GT, De Groat WC: A comparison of inhibitory effects of neuropeptide $\mathrm{Y}$ on rat urinary bladder, urethra, and vas deferens. Am J Physiol 1993;265: 537-543.

110 Maggi CA, Parlani M, Astolfi M, et al: Neurokinin receptors in the rat lower urinary tract. J Pharmacol Exp Ther 1988;246:308315.

111 Maggi CA, Patacchini R: Tachykinin NK1 receptor in the guinea-pig isolated proximal urethra: characterization by receptor selective agonists and antagonists. $\mathrm{Br} J$ Pharmacol 1992;106:888-892.

112 Parlani M, Conte B, Majmone S, et al: The contractile effect of tachykinins on human prostatic urethra: involvement of NK-2 receptors. J Urol 1990;144:1543-1545.

113 Palea S, Corsi M, Artibani W, et al: Pharmacological characterization of tachykinin NK2 receptors on isolated human urinary bladder, prostatic urethra and prostate. J Pharmacol Exp Ther 1996;277:700-705.

114 Busacchi P, Perri T, Paradisi R, et al: Abnormalities of somatic peptide-containing nerves supplying the pelvic floor of women with genitourinary prolapse and stress urinary incontinence. Urology 2004;63:591595.

115 Afiatpour P, Latifpour J, Takahashi W, et al: Developmental changes in the functional, biochemical and molecular properties of rat bladder endothelin receptors. NaunynSchmiedebergs Arch Pharmacol 2003;367: $462-472$.

6 Latifpour J, Fukumoto Y, Weiss RM: Regional differences in the density and subtype specificity of endothelin receptors in rabbit urinary tract. Naunyn-Schmiedebergs Arch Pharmacol 1995;352:459-468.
117 Wada Y, Latifpour J, Sanematsu H, et al: Age-related changes in contractile responses of rabbit lower urinary tract to endothelin. J Urol 2000;164:806-813.

118 Garcia-Pascual A, Larsson B, Andersson KE: Contractile effects of endothelin-1 and localization of endothelin binding sites in rabbit lower urinary tract smooth muscle. Acta Physiol Scand 1990;140:545-555.

119 Sullivan ME, Mumtaz FH, Khan MA, et al: Endothelins in the urinary tract. BJU Int 2000;86:97-106

120 Andersson KE, Henriksson L, Ulmsten U: Effects of prostaglandin E2 applied locally on intravesical and intraurethral pressures in women. Eur Urol 1978;4:366-369.

121 Schussler B: Comparison of the mode of action of prostaglandin E2 (PGE2) and sulprostone, a PGE2-derivative, on the lower urinary tract in healthy women: a urodynamic study. Urol Res 1990;18:349-352.

122 Thor KB: Serotonin and norepinephrine involvement in efferent pathways to the urethral rhabdosphincter: implications for treating stress urinary incontinence. Urology 2003;62(4 suppl 1):3-9.

123 Danuser H, Bemis K, Thor KB: Pharmacological analysis of the noradrenergic control of central sympathetic and somatic reflexes controlling the lower urinary tract in the anesthetized cat. J Urol 1995;274:820825 .

124 Thor KB, Katofiasc MA: Effects of duloxetine, a combined serotonin and norepinephrine reuptake inhibitor, on central neural control of lower urinary tract function in the chloralose-anesthesized female cat. J Pharmacol Exp Ther 1995;274:10141024.

125 Katofiasc MA, Nissen J, Audia JE, et al: Comparison of the effects of serotonin selective, norepinephrine selective, and dual serotonin and norepinephrine reuptake inhibitors on lower urinary tract function in cats. Life Sci 2002;71:1227-1236.

126 Bymaster FP, Dresfield-Ahmad LJ, Threlkeld PG, et al: Comparative affinity of duloxetine and venlafaxine for serotonin and norepinephrine transporters in vitro and in vivo, human serotonin receptor subtypes, and other neuronal receptors. Neuropsychopharmacology 2001;25:871-880.

127 Norton PA, Zinner NR, Yalcin I, et al: Duloxetine versus placebo in the treatment of stress urinary incontinence. Am J Obstet Gynecol 2002;187:40-48.

128 Dmochowski RR, Miklos JR, Norton PA, et al: Duloxetine versus placebo for the treatment of North American women with stress urinary incontinence. J Urol 2003; 170:1259-1263

129 van Kerrebroeck P, Abrams P, Lange R, et al: Duloxetine versus placebo in the treatment of European and Canadian women with stress urinary incontinence. $\mathrm{Br} \mathrm{J} \mathrm{Ob-}$ stet Gynaecol 2004;111:249-257. 
130 Boy S, Reitz A, Wirth B, et al: Facilitatory neuromodulative effect of duloxetine on pudendal motor neurons controlling the urethral pressure: a functional urodynamic study in healthy women. Eur Urol 2006;50: 119-125.

131 Malmqvist U, Hedlund P, Sward K, et al: Female pig urethral tone is dependent on Rho guanosine triphosphatases and Rho-associated kinase. J Urol 2004;171:1955-1958.

-132 Fukata Y, Mutsuki A, Kaibuchi K: RhoRho-kinase pathway in smooth muscle contraction and cytoskeletal reorganisation of non-muscle cells. Trends Pharmacol Sci 2001;22:32-39.

133 Hong SK, Kwak C, Chang Jeong B, et al: Involvement of Rho-kinase in the contractile mechanism of human ureteral smooth muscle. Neurourol Urodyn 2005;24:136141.

134 Malmqvist U, Hedlund P, Sward K, et al: Female pig urethral tone is dependent on Rho guanosine triphosphatases and Rho-associated kinase. J Urol 2004;171:1955-1958.

135 Blakeman PJ, Hilton P, Bulmer JN: Oestrogen and progesterone receptor expression in the female lower urinary tract, with reference to oestrogen status. BJU Int 2000;86: 32-38.

-136 Blakeman PJ, Hilton P, Bulmer JN: Cellular proliferation in the female lower urinary tract with reference to oestrogen status. BJOG 2001;108:813-816.

$\checkmark 137$ IosifCS, Batra S, Ek A, et al: Estrogen receptors in the human female lower urinary tract. Am J Obstet Gynecol 1981;141:817820 .

138 Levin RM, Shofer FS, Wein AJ: Estrogeninduced alterations in the autonomic responses of the rabbit urinary bladder. J Pharmacol Exp Ther 1980;215:614-618.
139 Zoubina EV, Smith PG: Expression of estrogen receptors alpha and beta by sympathetic ganglion neurons projecting to the proximal urethra of female rats. J Urol 2003;169:382-385.

140 Long CY, Liu CM, Hsu SC, Chen YH, Wu $\mathrm{CH}$, Tsai EM: A randomized comparative study of the effects of oral and topical estrogen therapy on the lower urinary tract of hysterectomized postmenopausal women. Fertil Steril 2006;85:155-160.

141 Hendrix SL, Cochrane BB, Nygaard IE, Handa VL, Barnabei VM, Iglesia C, Aragaki A, Naughton MJ, Wallace RB, McNeeley SG: Effects of estrogen with and without progestin on urinary incontinence. JAMA 2005;293:935-948.

142 Fantl JA, Cardozo L, McClish DK: Estrogen therapy in the management of urinary incontinence in postmenopausal women: a meta-analysis. First report of the Hormones and Urogenital Therapy Committee. Obstet Gynecol 1994;83:12-18.

143 Rosenzweig BA, Bolina PS, Birch L, et al: Location and concentration of estrogen, progesterone, and androgen receptors in the bladder and urethra of the rabbit. Neurourol Urodyn 1995;14:87-96.

144 Sajjad Y, Quenby S, Nickson P, et al: Immunohistochemical localization of androgen receptors in the urogenital tracts of human embryos. Reproduction 2004;128:331-339.

145 Toozs-Hobson P, Cutner A: Pregnancy and childbirth; in Cardozo L, Staskin D (eds) Textbook of Female Urology and Urogynaecology. Oxford, Isis Medical Media, 2001, pp 978-992.
146 Fritsch H, Pinggera GM, Lienemann A, et al: What are the supportive structures of the female urethra? Neurourol Urodyn 2006;25:128-134.

147 Häbler HJ, Jänig W, Koltzenburg M: Activation of unmyelinated afferent fibers by mechanical stimuli and inflammation of the urinary bladder in the cat. J Physiol (Lond) 1990;425:545-562.

148 de Groat WC: A neurologic basis for the overactive bladder. Urology 1997;50(suppl $6 \mathrm{~A}): 36-52$.

149 Szallasi A, Blumberg PM: Vanilloid (capsaicin) receptors and mechanisms. Pharmacol Rev 1999;51:159-211.

150 Avelino A, Cruz C, Cruz F: Nerve growth factor regulates galanin and c-jun overexpression occurring in dorsal root ganglion cells after intravesical resiniferatoxin application. Brain Res 2002;951:264-269.

151 Szoke E, Seress L, Szolcsanyi J: Neonatal capsaicin treatment results in prolonged mitochondrial damage and delayed cell death of B cells in the rat trigeminal ganglia. Neuroscience 2002;113:925-937.

152 Nordling L, Lundeberg T, Brolin J, Liedberg H, Ekman P, Theodorsson E: The role of sensory nerves in catheter-induced urethral inflammation. Eur Urol 1992;21:7578.

153 De Laet K, De Wachter S, Wyndaele JJ: Current perception thresholds in the lower urinary tract: Sine- and square-wave currents studied in young healthy volunteers. Neurourol Urodyn 2005;24:261-266.

154 Kinn AC, Nilsson BY: Urethral sensitivity in incontinent women. Eur Urol 2005;48: $116-120$.

155 Kessler TM, Studer UE, Burkhard FC: Increased proximal urethral sensory threshold after radical pelvic surgery in women. Neurourol Urodyn 2007;26:208-212. 